\title{
Öngyilkosság és antidepresszívumok, ökológiai vizsgálatok
}

\section{ZONDA TAMÁS ${ }^{1 *}$ - BOZSONYI KÁROLY² - KMETTY ZOLTÁN}

\author{
${ }^{1}$ Magyar Szuicidium-Prevenciós Társaság \\ ${ }^{2}$ Károli Gáspár Református Egyetem, Társadalom- és Kommunikációtudományi Intézet, \\ Kommunikáció Tanszék, Budapest \\ ${ }^{3}$ Eötvös Loránd Tudományegyetem, Társadalomtudományi Kar, Szociológiai Intézet, \\ Budapest
}

(Beérkezett: 2016. január 7.; elfogadva: 2016. április 9.)

\begin{abstract}
A szerzők az öngyilkosságok és az antidepresszív szerek forgalma közötti összefüggés problémáit vizsgálták az ökológiai vizsgálatok irodalmára koncentrálva. Több gyakorlati és elméleti problémát találtak, amelyek megkérdőjelezik az ún. antidepresszív teóriát, amely szerint egy adott populációban az antidepresszívumok (AD-k) emelkedő használata a csökkenő öngyilkossági ráták meghatározó oka lenne.
\end{abstract}

1. Az ökológiai vizsgálatokban nem ismert a populációban öngyilkossá vált depressziós személyeknél az antidepresszívum használatának ténye, ami könnyen az ún. ökológiai tévkövetkeztetés oka lehet, valótlan viszonyt jelezve.

2. Alapprobléma az ökológiai vizsgálatoknál, hogy a korreláció csak a két vizsgálandó jelenség közötti együttjárást jelzi, kauzalitást nem. A jelen esetben a helyzetet tovább bonyolítja az a tény is, hogy az AD-k nem az öngyilkosságra hatnak direkt módon, hanem egy pszichiátriai betegségre, amelynek egyik szövődménye lehet az öngyilkosság. Az antidepresszívumok tehát áttételes (indirekt), preventív hatást igyekeznek kifejteni nem ismert számú depressziós betegek ismeretlen hányadánál, nem kiszámítható hatásban és mértékben.

3. A szerzők nem találtak adatot az irodalomban a depressziós és nem-depressziós betegek által használt AD-mennyiség megoszlásáról. Egy hivatalos hazai adatbázis vizsgálatára volt módjuk. Az OEP 4 éves (2007-2010) ambuláns AD-forgalmában szétválogatták az egyes BNO kódokkal jelzett betegek csoportjait: F00-F03; F063; F25; F30-39; F40-48; F50 és Egyéb kategóriák szerint. Az analízis során kiderült, hogy az AD-k 53,93\%-át használták csak a valóban magas öngyilkossági rizikót magukban hordozó (F25 és F 30-39) betegek, míg az AD-k közel másik felét (46,07\%) minden más (magas rizikót nem hordozó) pszichiátriai vagy nem pszichiátriai kódot kapott betegek. Az AD-k gyógyszertári forgalma tehát nem lehet indikátora a valóban kezelt depressziós betegeknek, illetve kezeléseik számának.

\footnotetext{
* Levelezó szerzó: dr. Zonda Tamás, 1121 Budapest, Mártonhegyi út 22/d.

E-mail: zondat@t-online.hu
} 
4. A szerzők több olyan ökológiai vizsgálatot találtak, amelyek közül több nem tudta bizonyítani az AD-k használata és az öngyilkossági ráták közötti inverz kapcsolatot, vagy nem konzekvens, vegyes eredmények jelentkeztek.

Kulcsszavak: öngyilkosság, antidepresszívumok használata, ökológiai vizsgálatok, gyakorlati és elméleti problémák

In memoriam Buda Béla

\section{Bevezetés, előzmények}

Az 1980-as évek közepéig az öngyilkossági ráták a jelenleginél lényegesebben magasabbak voltak egész Európában, Magyarország pedig sokáig világelső volt. Ezt követően - viszonylag hirtelen és máig kiderítetlen okokból - csökkenni kezdett az öngyilkosságok száma úgy Nyugat-, mint KözépKelet-Európa csaknem minden országában. A volt szocialista országok többségében ez a csökkenés később, 1988-1992 között jelentkezett. Ez az időszak egybeesett ezen országok függetlenné válásával, ami fundamentális társadalmi, politikai, gazdasági és morális átalakulást jelentett. Magyarország és több önállóvá vált ország népessége is telve volt bizakodással, reményekkel, optimizmussal teli kíváncsisággal, ezért indokolt az a feltételezés, hogy az adott országok minden lakosát mélyen érintő paradigmaváltás és az öngyilkossági ráták csökkenése között ok-okozati összefüggés van (Mäkinen, 2000; Zonda, 2013). Az Európai Unió országaiban az öngyilkossági ráták csökkenésével egy idóben számos negatív jelenség redukciója is bekövetkezett (közlekedési balesetek, dohányzás, alkoholfogyasztás, ISZB, cerebrovascularis betegségek okozta halálozás), ugyanekkor meredeken emelkedett a GDP, csökkent az infláció és a munkanélküliség (Titelman és mtsai, 2013; WHO HFA-DB, 2014). Kínában is észlelhető volt a gazdasági fellendülést követően az öngyilkossági hajlandóság csökkenése (Zhang és mtsai, 2010).

A ráták csökkenése okainak további kutatása során gomba módra kezdtek szaporodni az SSRI szerek kiváló hatását bizonyító esetkontrollált és randomizált kontrollcsoportos klinikai vizsgálatok (RCT), számuk 2008-ban már 4000 fölé emelkedett (Joannidis, 2008). Ekkortájt született meg az „,antidepresszívum teória" is, amely szerint az öngyilkosságok számának csökkenése mögött is az új antidepresszíuumok (a továbbiakban: AD-k) kereskedelmi forgalmának emelkedése áll. Máig kérdés, hogy miért nem csökkentek, inkább emelkedtek, Európa-szerte az öngyilkosságok már a 60-as évek közepétól, amikor az első hatékony AD-k megjelentek? Az új AD-k emelkedő kereskedelmi forgalma és a csökkenő öngyilkossági számok közötti inverz korreláció bizonyításához a gyógyszergyárak intenzív marketingtevékenysége is hoz- 
zájárult. A szakma lassan két táborra szakadt világszerte: az SSRI szerek apologétáira és a (joggal) kétkedőkre, differenciáltabb megközelítést javaslókra. Az irodalomban ugyanis egyre szaporodtak azok az adatok, miszerint a gyógyszergyárak a negatív eredmények, mellékhatások cáfolatára sorra rendelték meg az új antidepresszánsaik igen jótékony hatását bizonyító „,kutatásokat”, a kedvezőtlen eredményeket nem közölték, a kedvező eredményekből több kiadvány, szelektált közlések és riportok jelentek meg. Ugyanakkor a placebokontrollos vizsgálatok sora nem mutatott érdemi eredményt, sőt a 24 év alattiak körében emelkedett az önsértő viselkedések száma és egyéb mellékhatásokra is fény derült. Mindezekről a hazai szakmának főként magyar nyelvú szakirodalmát olvasók egy 2004-ben megjelent összefoglaló könyvből értesülhettek részletesen (Szendi). Ezt követóen egy nívós eszmecsere helyett „,a pszichiátria hazai rendszerében a nyílt viták megbántódásokba, elfojtott botrányokba torkolltak" (Buda, 2011, 368. o.).

Pedig Van Praag már 2002-ben feltette a kérdést, hogy az antidepresszívum érája alatt miért nem mutatkozott szignifikáns csökkenés az öngyilkossági rátákban, és gondos elemzéssel összefoglalta a lehetséges okokat (van Praag, 2002). De Leo $(2002,2004)$ két ízben is tömören áttekintette az öngyilkosság-kutatás állását, megállapítva, hogy a hatalmas mennyiségú irodalom ellenére máig sincs tudományos bizonyítékunk (tudásunk) az öngyilkos magatartás előrejelzéséról, megelőzéséról. (Az egyik legfrissebb példa a Germanwings 9525-ös járat depressziós másodpilótájának kiterjesztett öngyilkossága).

A több ezer randomizált kontrollcsoportos vizsgálatnál felmerülő problémák szaporodtak (Hawton és mtsai, 1988), így a vizsgált résztvevók alacsony mintaelemszáma (Gunnel \& Frankel, 1994), a terápiarezisztens betegek bennmaradása a vizsgált mintákban (van Praag, 2003); a programok rövid időtartama (Goldney, 2000). Hiányoznak továbbá a retrospektív értékelések; nincs vagy nem megfelelő a kontrollcsoport alkalmazása (Hawton és mtsai, 1999). Mindezek a módszertani korlátok külön-külön is téves (torzult) eredményhez vezetnek. Másrészt nagyon keveset tudunk azokról a tényezőkről, amelyek az öngyilkosság ellen hatnak, mint amilyen a megküzdési (coping) készség, a problémamegoldó képességek, a szociális támogatás vagy az egyén kapcsolati rendszerének gazdagsága (De Leo, 2004). Elhanyagolt a pszichoterápia, pedig az öngyilkosság-prevencióban, a recidívák csökkentésében és a krízisállapotokban elsőként lenne választandó; az enyhe és közepes fokú depressziókban hatása azonos a gyógyszerekével (Ajtay, Bérdi, Szilágyi, \& Perczel-Forintos, 2012; Brown és mtsai, 2005; Paykel, 2007; Towsend, Hawton, \& Altman, 2001).

A kritikus vélemények tovább szaporodtak (pl. Aursnes, Tvete, Gaasemyr, \& Natvig, 2006; Cougnard és mtsai, 2009; De Leo, Draper, Snowdon, \& Kölves, 2013; Didham, Mcconnel, Blair, \& Reith, 2005; Fergusson és mtsai, 
2005; Fournier és mtsai, 2010; Martinez és mtsai, 2005; Roose és mtsai, 2004; Thase, 2008; Wheeler és mtsai, 2008), éppúgy, mint a közlés-etikai kifogások (Kirsch és mtsai, 2008; Kirsch, 2009; Melander, Ahlquist-Rastad, Meijer, \& Beermann 2003; Sinyor és mtsai, 2012; Turner, Matthews, Linardatos, Tell, \& Rosenthal, 2008). Egy markánsan kritikus szerző véleménye szerint a sok randomizált kontrollcsoportos vizsgálat klinikailag nem mutatott ki releváns hatást, és az eredmények szelektív és torz (biased) interpretációja $a z$ AD-k látszólag bizonyitékokon alapuló mítoszát sugallta (Joannidis, 2008).

Tény, hogy a kritikus oldal kételyei megalapozottnak bizonyultak, mert már 2007-ben megállapítást nyert, hogy "gyorsabban ható, jobb és biztonságosabb" antidepresszívumokra lenne igény (Gelenberg és mtsai, 2008). Szakértői csoport alakult a University of Arizona Pszichiátriai Tanszéke és a Best Practice Project Management Inc. égisze alatt. Negyvenöt, az ADkutatásokkal foglalkozó szakértőt hívtak össze 2007 júliusában, amelyen kormányzati szervek (US Food and Drug Administration; National Institute of Mental Health) és a gyógyszeripar képviselői is részt vettek annak érdekében, hogy meghatározzák a klinikai vizsgálatok módszertanának állását az antidepresszánsok területén. Úgy határoztak, hogy jól megtervezett proof-of-concept (POC) vizsgálatokat kell elindítani az új AD-k központi idegrendszeri és klinikai hatásainak vizsgálatára, valamint a jövő teendőinek feltérképezésére (Gelenberg és mtsai, 2008; Thase, 2008). A szakértői csoport részletesebb terveit Kéri (2008) ismertette a hazai irodalomban.

\section{Az ökológiai vizsgálatok problémái az öngyilkosság-kutatásban}

2.1. A több ezer RCT és esetkontrollált kutatást ért számos kritikát követően a nemzetközi szakirodalomban megjelentek az ún. ökológiai vizsgálatok. Ezek lényege az, hogy egy adott országban (népességben), egy időszak alatt felírt és/vagy megvásárolt $\mathrm{AD}$-mennyiség és a népességben észlelt öngyilkossági ráta között keresnek statisztikai módszerrel összefüggést, többnyire korrelációs számítással. Ezen eljárás szerint, ha két adatsor között negatív (inverz) korrelációt találnak, azt egyértelmú bizonyítékként kezelik amellett, hogy az emelkedő AD-forgalom (használat) a meghatározó oka az esetleg csökkenő öngyilkossági rátának az adott populációban. Számos szerző jelezte azonban, hogy az ökológiai vizsgálatokban feltett kérdések megválaszolására a korrelációs technika már az aggregált adatok miatt sem alkalmas, de több metodológiai probléma is felmerül, ezért szofisztikáltabb módszerekre van szükség (Bramness \& Walby, 2009; Default \& Klar, 2011; Greenland \& Robins, 1994; Greenland, 1992; King, 2013; Morgenstern, 1995; Plummer \& 
Clayton, 1966; Wakefield, 2008; Zimmerman, 1990). Ezek közül emelünk ki egy-két hazai vonatkozásban is különösen szem elött tartandó szempontot. A szigorúan statisztikai-matematikai problémákat (pl. idősorok hossza, stacionaritás biztosítása) egy másik közleményben részleteztük (Kmetty, Bozsonyi, \& Zonda, 2016).

2.2. Az ökológiai vizsgálatok további komoly problémája - amely egyben egy országos monitoring bevezetését is sürgeti -, hogy a pontos regisztráció hiányában nem ismerjük a depressziós személyeknek, illetve a más betegségben szenvedóknek felírt antidepresszívumok megoszlását sem. Az AD-kat ugyanis számos más pszichiátriai, neurológiai vagy más betegség, állapot kezelésére is használja az orvostudomány, amelyek nem, vagy lényegesen alacsonyabb öngyilkossági rizikót hordoznak, mint a major depresszió (pl. pánikzavar, fóbiák, poszttraumás stressz-zavar, generalizált szorongásos zavar, kényszerbetegség, evészavarok, premenstruális diszfória, fülzúgás, fájdalomszindrómák, demenciák, enuresis stb).

A különböző szorongásos-, fóbiás-, kényszeres- és evészavarok önmagukban nem hordozzák a befejezett öngyilkosság kockázatát. A szakirodalom többsége szerint ritkán fordul elő kísérlet, inkább szuicid ideációk jelentkezhetnek (Beck, Steer, Sanderson, \& Skeie, 1991; Cox, Direnfeld, Swinson, \& Norton, 1994; Friedman, Jones, Cherneb, \& Barlow, 1992). Az esetleg bekövetkező öngyilkosság csak komorbid állapotokban fordul elő, ahol a depresszió vagy a személyiségzavar a hangsúlyosabb összetevő (Rihmer, Belsó, \& Barsi, 1994; Rudd, Dahm, \& Rajab, 1993; Zonda, Nagy, \& Lester, 2011).

Mindebból egyértelmúen következik, hogy a csak (major) depressziós betegeknek felírt antidepresszívumok megközelítöen pontos mennyisége és egyáltalán, a hazai AD-használat szerkezete ismeretlen.

Módunk nyílt a kérdés vizsgálatára az Országos Egészségügyi Pénztár (OEP) állományából kapott adatok alapján. Az összes antidepresszívum (NO6AA, NO6AB, NO6AG, NO6AX) országos, összesített gyógyszertári használatával volt lehetőségünk számolni a WHO által javasolt DDD/ 1000 fő/nap formátumban, a 2007 és 2010 közötti időszakra nézve. Mivel a vényeken csak 2006-tól kötelező a BNO-10 szerinti diagnózis feltüntetése hazánkban, lehetőségünk volt arra, hogy a BNO-10 (DSM-IV-TR-rel kompatibilis) kategóriái szerint szétválogassuk az AD-t kapott betegcsoportokat az 1. táblázatban felsoroltak szerint, úgymint F00-F03 (demenciák); F063 (organikus affektív zavarok); F25 (szkizoaffektív rendellenességek); F30-39 (affektív rendellenességek); F40-48 (neurotikus, stresszhez társuló és szomatoform rendellenességek); és F50 (evési zavarok). A neurológiai, illetve más okok miatt felírt AD-k az Egyéb kategóriába kerültek. A kórházi ADhasználat az országos fogyasztásnak mindössze 2,55\%-át tette ki 2007 és 
2010 között (OEP és IMS), tehát az országos AD-forgalom elenyésző része esik csak a kórházi kezelésekre, messze túlnyomó része a gyógyszertárakban zajlik, így az általunk alkalmazott eljárás az AD-használat megoszlásának országos vizsgálatára egyértelmúen alkalmas. (Az OEP az ambuláns [gyógyszertári] forgalmat, az International Medical Service Kft. a kórházi forgalmat is tartalmazza, ez utóbbi azonban diagnosztikus adatokat nem tartalmaz.)

Felmérésünk azt mutatta, hogy a vizsgált időszakban (2007-2010) az OEP által regisztrált, évente a gyógyszertárakban eladott AD-k 53,93\%-át rendelték a valóban magas öngyilkossági rizikót magukban hordozó F25 és F30-39 BNO kódot kapott betegeknek (1. táblázat). Hazánkban tehát az antidepresszívumok közel felét (46,07\%-át) a nem magas öngyilkossági rizikójú depressziós betegek vagy a rizikót nem hordozók számára írták fel az általunk vizsgált 4 évben, ami alighanem a vizsgált évek előtt és azóta is így volt, illetve van. Nem meglepő adat, hogy az AD-t felíró orvosok 55,2\%-a pszichiáter, a többi vényt túlnyomó részben a háziorvosok írják fel.

1. táblázat. A jelzett BNO kórformákban szenvedó járóbetegek által kiváltott antidepresszívumok (DDD/1000fö/nap)

százalékos megoszlása Magyarországon (2007-2010)

\begin{tabular}{|l|c|c|c|c|l|}
\hline \multirow{2}{*}{ BNO-kód } & \multicolumn{4}{|c|}{ Év } & \multirow{2}{*}{ Betegségcsoport } \\
\cline { 2 - 5 } & $\mathbf{2 0 0 7}$ & $\mathbf{2 0 0 8}$ & $\mathbf{2 0 0 9}$ & $\mathbf{2 0 1 0}$ & \\
\hline Egyéb & 9,86 & 7,9 & 7,33 & 6,98 & \\
\hline F40-F50 & 32,92 & 32,76 & 32,23 & 31,8 & Szorongás, evészavar \\
\hline F06.3 & 3,67 & 4,58 & 5,47 & 6,16 & Org. hangulatzavar \\
\hline F25-F25.9 & 1,13 & 1,19 & 1,11 & 0,09 & Szkizoaffektív zavar \\
\hline F30-F39 & 51,64 & 53,04 & 53,45 & 54,09 & Hangulatzavarok \\
\hline
\end{tabular}

2.3. A fenti adatok egyben az ökológiai vizsgálatok másik csapdáját is jelzik, nevezetesen az expozíció nagyságát (Bramness \& Walby, 2009; Plummer \& Clayton, 1966), vagyis azt, hogy van-e elegendő kockázatnak kitett személy ahhoz, hogy a teljes népesség kockázatának változását képviselje? Hazánkban még a kezelt depressziós betegek számát is csak becsülni tudjuk. Az ismert (kezelésre jelentkezett) betegek közül nem ismerjük a (tankönyvi adatnak számító) kb. 40\% körüli nem együttmúködők (non-compliance), illetve a 30\% körüli terápiarezisztens betegek számát. A KSH a 2010-es év folyamán 67656 hangulatzavarban szenvedőt jelez a pszichiátriai gondozókban és a kórházi osztályokon (KSH, 2011). Nem tudni azonban, hogy mennyi közülük a valóban magas öngyilkossági rizikót hordozó major depressziós 
beteg, és nem ismerjük a gondozói-kórházi kezelések átfedési arányát sem. Mint jeleztük, az AD-k csaknem felét (44,8\%) a háziorvosok írják fel Magyarországon, akiknek túlterheltsége miatt legfeljebb arra van idejük, hogy a szakorvosi engedély birtokában (1-3 havonta) felírják az antidepresszívumot, ezek az alkalmak azonban nem tekinthetők „,kezelési alkalomnak"; egyébként nem is várható el tólük szakellátás.

Az előző két pontban taglaltak miatt és alapján az AD-k gyógyszertári kiváltási száma egyáltalán nem tekinthető a depressziós betegek, illetve kezeléseik száma indikátorának, még kevésbé a major depresszióban szenvedókének. Távol vagyunk tehát attól, hogy olyan gyakori major depresszió kezelés számról beszélhessünk Magyarországon, amely egy bizonyos érték fölé emelkedvén az öngyilkosság-megelőző hatást populáció szinten képviselni tudná.

2.4. Az ökológiai vizsgálatok során jelentkező további alapvető probléma tehát - mint jeleztük és csak fontossága miatt ismételjük -, hogy nem ismerjük a népességben az igen különböző depressziós állapotokban szenvedők megoszlását, még a szuicidológiai szempontból legfontosabb major depressziós betegek számát sem. Magyarországon kevés, eltérő mérőeszközzel történt vizsgálat áll rendelkezésre, kis mintákon mérve (Szádóczky, Papp, Vitray, \& Füredi, 2000; Zonda, Bartos, \& Nagy, 2000; Zonda \& Paksi, 2001), amely azt jelzi, hogy egy folyamatos országos monitorozás bevezetésére lenne égető szükség.

2.5. A monitorozással sokkal pontosabb választ kaphatnánk arra a másik alapvető kérdésre is, hogy hazai viszonyok között a (major) depresszióban szenvedő betegek közül hány százalék lesz öngyilkos. Ez a kérdés máig nem tisztázott. A nemzetközi szakirodalomban egy régebbi vizsgálat 15\%-ot mutatott (Guze \& Robins, 1970), amit azóta is „kontrollálatlanul és kritika nélkül idéz több közlemény és kézikönyv" (Bostwick \& Pankratz, 2000, 1925. o.). Modernebb módszerekkel történt vizsgálataik szerint kisebb szám(ok)ról van szó.

2.6. A receptet kapó betegek megközelítóleg pontos (standardizált) diagnózisa sem megoldott. Ez egyre nagyobb probléma, mert a depresszió diagnózisa az utóbbi évtizedekben parttalanul kitágult, azaz olyan állapotok kapnak "depresszió" diagnózist, amelyek az élet történéseinek törvényszerú velejárói évezredek óta, gyógyszeres kezelésre mindenesetre nem szorulnak. (Lásd a depresszív zavarok számát a DSM legújabb változatában.) „Az egészségügy, az orvosi tevékenység a mindennapi állapotok egyre szélesebb körét vonja be a patológia búvkörébe és minősíti patológiásnak, majd ajánl rá remediumot is" (Tringer, 2003, 530. o.). A medikalizáció folyamata ez, amelyről több prominens hazai írás olvasható (Bánfalvi, 2003; Buda, 2010; Kovács, 2007; Pikó, 2003; Szebik, 2014). 
2.7. Az sem ismert az ökológiai vizsgálatokban, hogy az öngyilkos áldozatok hány százaléka állt adekvát $A D$-kezelés alatt tettének elkövetésekor, ami egyértelmúen magában hordozza az ökológiai tévkövetkeztetés (ecological fallacy) lehetóségét. Könnyen elképzelhető ugyanis, hogy a valós adatok birtokában az emelkedett AD-használatnak tulajdonított öngyilkosság-csökkenést azok körében találnánk, akik nem is részesültek antidepresszív kezelésben (Piantadosi, Byar, \& Green, 1998; Robinson, 1950).

2.8. Az ökológiai vizsgálatoknál - mint már jeleztük - csak a két vizsgálandó jelenség közötti együttjárás jelentkezhet, ami nem jelent kauzalitást. A jelen esetben a helyzetet tovább bonyolítja az a tény is, hogy az antidepresszívumok nem az öngyilkosságra hatnak direkt módon, hanem egy pszichiátriai betegségre, amelynek egyik szövődménye lehet az öngyilkosság. $\mathrm{Az}$ AD-k tehát áttételes (indirekt), preventív hatást igyekeznek kifejteni nem ismert számú depressziós betegek ismeretlen hányadánál, nem kiszámitható hatásban és mértékben.

Úgy túnik továbbá, hogy számos kapcsolat mutatható ki az öngyilkossági ráták és más gyógyszerek használata között. Norvégiában például az öngyilkosságok csökkenése és az angiotensin-II-receptor blokkolók növekvő értékesítése között találtak markáns negatív irányú korrelációt (Bramnees \& Walby, 2009). Az OEP-adatok alapján ugyanez tapasztalható hazánkban a koleszterinszintet csökkentő sztatinok eladása és az öngyilkossági ráták alakulása között (a 2000 és 2010 közötti időszakban). Még sincs kellő elméleti alapunk annak kijelentéséhez, hogy a sztatin gyógyszercsoportnak, az antidepresszánsokhoz hasonló mértékben emelkedő használata okozta volna az öngyilkosságok számának hazai csökkenését. Inkább arról vannak jelentős szakirodalmi adatok, miszerint az alacsony koleszterinszint depresszogén és öngyilkossági késztetést fokozó hatású (Engelberg, 1992; Golier, Marzuk, Leon, Weiner, \& Tardiff, 1995; Manfredini és mtsai, 2000; Zureik, Courbon, \& Ducimetière, 1996). Mellesleg a megsokszorozódott sztatinfogyasztás kiemelése és túlhangsúlyozása a cerebrovascularis halálozás csökkenésében is tudománytalan álláspont lenne.

2.9. Szükséges megjegyezni, noha magyarázatot aligha igényel, hogy az ökológiai vizsgálatokban sokszor szerepel az AD-felírás, -kiváltás és -használat, amelyek egymástól jelentősen eltéró értelmú szavak, s a fogalmak nem pontos használata könnyen eredményezhet téves összefüggéseket. 


\section{Ellentmondó eredményt mutató ökológiai vizsgálatok}

A fentebb felsorolt és a metodikai problémák miatt korántsem meglepő, ha az alábbiakban több olyan ökológiai tanulmányt tudunk említeni, amelyek nem találtak inverz összefüggést az emelkedő AD-rendelés (-használat) és az öngyilkossági ráták között, vagy vegyes (bizonytalan) eredmény mutatkozott (2. táblázat). Az idevágó irodalmat a Medline (PubMed) és részben a Cochrane Database of Systematic Review adatbázisaiból nyertük. A táblázatban nem szerepel, de utalnunk kell egy metaanalízisre (1970-2007), amely a témánkat illető 19 ökológiai vizsgálatból csak nyolcat talált elfogadhatónak (Baldessarini és mtsai, 2007) és indokolt jelezni pár markáns metodikai bírálatot is, amelyek kommentárként jelentek meg (Draper, 2003; Moncrieff \& Pomerleau, 2000; Moncrieff, 2003).

2. táblázat. Az antidepresszívumok használata

és az öngyilkossági ráták összefüggéseit ökológiai módszerrel vizsgáló, negatív vagy kevert eredménnyel járó kutatások

\begin{tabular}{|l|l|l|l|l|}
\hline \multicolumn{1}{|c|}{ Forrás } & \multicolumn{1}{|c|}{ Ország } & $\begin{array}{c}\text { Vizsgálat } \\
\text { ideje }\end{array}$ & $\begin{array}{c}\text { AD-használat és } \\
\text { öngyilkossági ráta }\end{array}$ & \multicolumn{1}{|c|}{ Eredmény } \\
\hline Oravecz (1999) & Szlovénia & $1986-1990$ & & $\begin{array}{l}\text { nincs } \\
\text { kapcsolat }\end{array}$ \\
\hline $\begin{array}{l}\text { Oravecz és mt- } \\
\text { sai (2003) }\end{array}$ & Szlovénia & $1985-1997$ & & $\begin{array}{l}\text { nincs } \\
\text { kapcsolat }\end{array}$ \\
\hline $\begin{array}{l}\text { Kapusta és } \\
\text { mtsai (2009) }\end{array}$ & Ausztria & $1991-2005$ & $\begin{array}{l}\text { együtt hatott az AD } \\
\text { és a pszichoterapeuták } \\
\text { súrúsége" }\end{array}$ & $\begin{array}{l}\text { vegyes } \\
\text { kapcsolat }\end{array}$ \\
\hline $\begin{array}{l}\text { Barbui és } \\
\text { mtsai (1999) }\end{array}$ & Olaszország & $1998-1996$ & & $\begin{array}{l}\text { nincs } \\
\text { kapcsolat }\end{array}$ \\
\hline $\begin{array}{l}\text { Guaiana és } \\
\text { mtsai (2005) }\end{array}$ & Olaszország & $1955-2000$ & $\begin{array}{l}\text { nincs } \\
\text { kapcsolat }\end{array}$ \\
\hline $\begin{array}{l}\text { Guaiana és } \\
\text { mtsai (2011) }\end{array}$ & Olaszország & $2000-2005$ & $\begin{array}{l}\text { nincs } \\
\text { kapcsolat }\end{array}$ \\
\hline $\begin{array}{l}\text { Kelly és mtsai } \\
(2003)\end{array}$ & Írország & $1988-1999$ & $\begin{array}{l}\text { AD-használat } \uparrow \\
\text { öngyilkossági ráta } \uparrow\end{array}$ & $\begin{array}{l}\text { nincs } \\
\text { kapcsolat }\end{array}$ \\
\hline $\begin{array}{l}\text { Largey és } \\
\text { mtsai (2009) }\end{array}$ & Írország & $1984-2002$ & $\begin{array}{l}\text { AD-használat } \uparrow \\
\text { öngyilkossági ráta } \uparrow\end{array}$ & $\begin{array}{l}\text { nincs } \\
\text { kapcsolat }\end{array}$ \\
\hline $\begin{array}{l}\text { Wheeler és } \\
\text { mtsai (2008) }\end{array}$ & UK & $2003-2008$ & $\begin{array}{l}\text { AD-használat } \uparrow / ~ \\
\text { változott }\end{array}$ & $\begin{array}{l}\text { nincs } \\
\text { kapcsolat }\end{array}$ \\
\hline
\end{tabular}




\begin{tabular}{|c|c|c|c|c|}
\hline Forrás & Ország & $\begin{array}{l}\text { Vizsgálat } \\
\text { ideje }\end{array}$ & $\begin{array}{l}\text { AD-használat és } \\
\text { öngyilkossági ráta }\end{array}$ & Eredmény \\
\hline $\begin{array}{l}\text { Morgan és } \\
\text { mtsai (2004) }\end{array}$ & UK & 1993-2002 & aggregált adatok & $\begin{array}{l}\text { nem } \\
\text { bizonyító }\end{array}$ \\
\hline $\begin{array}{l}\text { Biddle és } \\
\text { mtsai (2008) }\end{array}$ & UK & 1968-2005 & aggregált adatok & $\begin{array}{l}\text { nem } \\
\text { bizonyító }\end{array}$ \\
\hline $\begin{array}{l}\text { Gibbons és } \\
\text { mtsai (2005) }\end{array}$ & UK & 1996-1998 & aggregált adatok & $\begin{array}{l}\text { nem } \\
\text { bizonyító }\end{array}$ \\
\hline $\begin{array}{l}\text { Kessler és } \\
\text { mtsai (2005) }\end{array}$ & USA & $\begin{array}{l}1990-1992 \\
2001-2003\end{array}$ & $\begin{array}{l}\text { ellentmondó } \\
\text { eredmények }\end{array}$ & $\begin{array}{l}\text { nincs } \\
\text { kapcsolat }\end{array}$ \\
\hline $\begin{array}{l}\text { Safer és Zito } \\
\text { (2007) }\end{array}$ & WHO, USA & 2007 & & $\begin{array}{l}\text { nincs } \\
\text { kapcsolat }\end{array}$ \\
\hline $\begin{array}{l}\text { Helgason és } \\
\text { mtsai (2004) }\end{array}$ & Izland & 1950-2000 & $\begin{array}{l}\text { AD-használat } \uparrow / / \\
\text { öngyilkossági ráta nem } \\
\text { változott }\end{array}$ & $\begin{array}{l}\text { nincs } \\
\text { kapcsolat }\end{array}$ \\
\hline $\begin{array}{l}\text { Bjarnason } \\
(1982)\end{array}$ & Izland & 1965-1978 & $\begin{array}{l}\text { pszichiátriai ellátás } \uparrow / \\
\text { öngyilkossági ráta nem } \\
\text { változott }\end{array}$ & $\begin{array}{l}\text { nincs } \\
\text { kapcsolat }\end{array}$ \\
\hline $\begin{array}{l}\text { Søndergård és } \\
\text { mtsai (2006) }\end{array}$ & Svédország & 1995-1999 & & $\begin{array}{l}\text { vegyes } \\
\text { kapcsolat }\end{array}$ \\
\hline $\begin{array}{l}\text { Johannessen } \\
\text { és mtsai (2011) }\end{array}$ & Norvégia & 1990-2006 & $\begin{array}{l}\text { pszichiátriai ellátás } \uparrow \text { / } \\
\text { mortalitás változatlan }\end{array}$ & $\begin{array}{l}\text { nincs } \\
\text { kapcsolat }\end{array}$ \\
\hline $\begin{array}{l}\text { Reseland és } \\
\text { mtsai (2006) }\end{array}$ & $\begin{array}{l}\text { skandináv } \\
\text { országok }\end{array}$ & 1990-1999 & $\begin{array}{l}\text { öngyilkossági ráta elóbb } \\
\downarrow \text { mint az AD-használat } \uparrow\end{array}$ & $\begin{array}{l}\text { nem } \\
\text { bizonyító }\end{array}$ \\
\hline $\begin{array}{l}\text { Dahlberg és } \\
\text { Lundin (2005) }\end{array}$ & Svédország & $\begin{array}{l}\text { 1990-es } \\
\text { évek }\end{array}$ & $\begin{array}{l}\text { csökkenés csak a fiatalok } \\
\text { körében }\end{array}$ & $\begin{array}{l}\text { vegyes } \\
\text { kapcsolat }\end{array}$ \\
\hline $\begin{array}{l}\text { Zahl és mtsai } \\
(2010)\end{array}$ & $\begin{array}{l}\text { skandináv } \\
\text { országok }\end{array}$ & 1990-1998 & & $\begin{array}{l}\text { nincs } \\
\text { kapcsolat }\end{array}$ \\
\hline $\begin{array}{l}\text { Titelman és } \\
\text { mtsai (2013) }\end{array}$ & $\begin{array}{l}\text { skandináv } \\
\text { országok }\end{array}$ & 1980-2009 & $\begin{array}{l}\text { AD-használat } \uparrow \text { / } \\
\text { öngyilkossági ráta } \downarrow \text { / } \\
\text { gazdasági-szociális } \\
\text { helyzet is javult }\end{array}$ & $\begin{array}{l}\text { vegyes } \\
\text { kapcsolat }\end{array}$ \\
\hline $\begin{array}{l}\text { Ludwig és } \\
\text { mtsai (2009) }\end{array}$ & 26 ország & 1980-2000 & $\begin{array}{l}\text { adat- és metodikai } \\
\text { problémák (l. szöveg) }\end{array}$ & $\begin{array}{l}\text { nem } \\
\text { bizonyító }\end{array}$ \\
\hline $\begin{array}{l}\text { Gusmão és } \\
\text { mtsai (2013) }\end{array}$ & 29 ország & 1980-2009 & $\begin{array}{l}\text { metodikai problémák } \\
\text { (l. szöveg) }\end{array}$ & $\begin{array}{l}\text { nem } \\
\text { bizonyító }\end{array}$ \\
\hline $\begin{array}{l}\text { Alameda- } \\
\text { Palacios } \\
\text { és mtsai (2013) }\end{array}$ & Andalúzia & 1975-2012 & & $\begin{array}{l}\text { nincs } \\
\text { kapcsolat }\end{array}$ \\
\hline
\end{tabular}

Megjegyzés: $\downarrow=$ csökkent; $\uparrow=$ emelkedett 
Szükségesnek látjuk röviden részletezni két, több országon átívelő vizsgálat problémáit. Ludwig, Marcotte és Norberg (2009) tanulmányukban a 95\% feletti $\mathrm{R}^{2}$ illeszkedés mutatók azt jelzik, hogy az általuk használt modellek valószínúleg jelentősen túlillesztettek (ebben azért nem lehetünk biztosak, mert a tudományos közlés standardjaitól eltérve nem közlik modelljeik szabadságfokait). Ez az extrém magas $R^{2}$ mutató még ökológia modellek esetében is kirívó. Azt sem közlik, hogy mekkora a változók között a multikollinearitás (Kmetty és mtsai, 2016). Túl az alapvetó matematikai problémákon, hibaforrást jelent, hogyha minél több országot vonunk be az ökológiai vizsgálatba (eltérő adatbázisok, igen különböző egészségügyi rendszerek, markáns kulturális különbségek). Azt találták például, hogy az öngyilkossági ráta csökkenése erősen korcsoportfüggő, de az AD-k használatának korcsoport szerinti bontása nem állt rendelkezésükre. A közlemény másik komoly problémája, hogy az új antidepresszívumoknak a kereskedelemben történt - szerzők által jelzett - megjelenése több országban nem valós, mert a szerzók által megadott forgalomba kerülés dátumai (feltehetóen) gyári adatok, nem az adott országok hivatalos szerveinek engedélyezési dátuma (Ausztria, Belgium: Michael Mayr, Dánia: Anette Erlangsen, Spanyolország: Pilar A. Sáíz személyes közlései). Az új típusú AD-k emelkedő fogyasztása a legtöbb skandináv országban is később kezdődött, mint az öngyilkossági ráták csökkenése (Reseland, Bray, \& Gunnel, 2006), miként az Magyarországon is történt (Zonda, 2013).

A másik tanulmány szerzői (Gusmão és mtsai, 2013), munkájuk elején korrelációs módszerekkel elemzik a nyers összefüggést az öngyilkossági idősorok és a gyógyszerfogyasztás között, amely metodika problémás voltát már jeleztük. Tanulmányuk második felében komplexebb modelleket használnak, amelyek első pillantásra meggyőző eredményt mutatnak a gyógyszerek hatásáról. Azonban maguk is elismerik, hogy az idő komponenst ki kellett venniük az elemzésből, mert az lenullázott minden más összefüggést, a bizonyítani kívánt $\mathrm{AD}$-hatást is beleértve. Ráadásul a modellek illeszkedési statisztikáit se közlik minden esetben, így az sem derül ki, hogy a GDP és a gyógyszerfogyasztás közötti, feltehetóen igen erős pozitív korreláció okozta multikollinearitás jelentett-e problémát az illeszkedésben (Kmetty és mtsai, 2016). Közölt ábráik egy része is mutatja a már említett tényt, hogy sok országban az öngyilkossági ráták csökkenése már elkezdődött az AD-k használatának felfutása előtt (Magyarország, Észtország, Szlovákia, Szlovénia, Horvátország, Bulgária, Svájc, Lettország). Vizsgálatuk szerint az AD-k emelkedő használata következtében az öngyilkosságok csökkenése egész Európa országaiban észlelhető, kivéve Portugáliát. A WHO adatai szerint (WHO-HFA, 2014) azonban Csehszlovákiában már 1970 óta (!) csökken az öngyilkosságok száma, az ország 1993-ban történt szétválása után a folyamat csak folytatódott Csehországban és Szlovákiában. A vizsgált időszak- 
ban inkább stagnálás volt megfigyelhető pár országban (Hollandia, Izland, Izrael); emelkedés mutatkozott Lengyelországban, Spanyolországban és Írországban, igen markáns emelkedés történt Máltában (WHO-HFA, 2014). A szerzők joggal jegyzik meg, hogy az általuk felsorolt számos limitáció és zavaró körülmény miatt igen óvatosan kell értelmezni eredményeiket. Konklúziójuk azon mondatával viszont messzemenően egyet kell érteni, hogy törekedni kellene az AD-k optimális használatának biztosítására azok számára, akik valóban rászorulnak, szemben sok olyannal, akik talán indokolatlanul szedik azokat.

A magyarországi vizsgálatokkal egy előző vizsgálatunkban részletesebben foglalkoztunk, (Kmetty és mtsai, 2016), ismétlésük jelen alkalommal nem lenne indokolt.

Érdemes viszont egy-két újabb keletű ökológiai vizsgálat eredményének említése, amelyek emlékeztetnek egy korábban történt vizsgálatra. Az a felmérés 100 ország adatait vizsgálta, és azt állapította meg, hogy a feltételezett inverz kapcsolattal ellentétben a mentális ellátás érdekében tett javító intézkedéseket követően az adott országokban az öngyilkosságok aránya emelkedett (Burgess, Pirkis, Jolley, Whiteford, \& Saxena, 2004). Egy nemzetközi vizsgálat nem talált kapcsolatot az öngyilkosságok aránya és a mentális egészségügy-politika különböző intézkedései között; sőt szignifikáns, pozitív irányú korreláció mutatkozott az öngyilkosságok száma és a teljes egészségügyi költségvetésnek a mentális egészségre költött hányada között; az öngyilkosságok aránya magasabb volt azokban az országokban, ahol jobbak a mentális egészségügyi szolgáltatások (több pszichiátriai ágy, pszichiáter, pszichiátriai ápoló, képzett mentális segítő szakember) (Shah, Bhandarkar, \& Bhatia, 2010). A WHO, az ENSZ Statistics Division és a Central Intelligence Agency World Fact forrásait felhasználva egy kutatás 191 ország rendelkezésre álló öngyilkossági adatait és a mentális egészségügyet szolgáló paramétereit vizsgálta. Szignifikáns, pozitív irányú kapcsolat mutatkozott az öngyilkossági ráták és a mentálhigiénés rendszer között (pszichiáterek száma, pszichiátriai ágyak száma). Sajátosan paradox állapotot talált ez a vizsgálat is: a jobb pszichiátriai ellátó rendszerrel rendelkező országokban magasabb az öngyilkossági ráta. Mivel a téma összetett, a talált eredmény interpretációja óvatosságot igényel, de a szerzők azt sugallják, hogy a populációalapú népegészségügyi stratégiák jobb eredményt hozhatnak a nemzeti öngyilkossági rátákban, mint az individuális szinten gyógyító egészségügyi szolgálatok (Rajkumar, Brinda, Duba, Thangadurai, \& Jacob, 2013). Az OECD országok adatbázisán végzett vizsgálat szerint statisztikailag szignifikáns, habár gyenge, pozitív irányú kapcsolatot tapasztaltak az AD-rendelés és az öngyilkossági ráták között (Kamat, Edgar, Niblock, McDowell, \& Kelly, 2014). 


\section{Megbeszélés és konklúziók}

1. Vizsgálatunk azt mutatta, hogy az ökológiai vizsgálatok - számos gyakorlati és elméleti probléma miatt - nem bizonyítják egyértelmúen azt a feltételezést, hogy egy adott populációban az antidepresszívumok emelkedó használata a csökkenő öngyilkossági ráták meghatározó oka lenne. Mivel az ökológiai vizsgálatokban nem ismert a vizsgált populációban öngyilkossá vált depressziós személyeknél az AD használatának ténye, az ilyen vizsgálatok eredményeiben mindenkor benne van az ún. ökológiai tévkövetkeztetés lehetósége.

2. Az OEP 4 éves mintájából kiderült, hogy Magyarországon az AD-k csaknem felét $(46,07 \%)$ nem major depressziós betegeknek rendelik. Az így lényegesen kisebb számú kezelésbe vett depressziós betegek közül sem ismert a nem együttmúködő (non-compliance) és a terápiarezisztens (non-responder) betegek száma. Mindezek miatt az antidepresszívumok kiváltásának száma nem lehet indikátora a valóban kezeltek, illetve a kezelések számának, vagyis nincs elegendő kockázatnak kitett személy, hogy a teljes népesség kockázatának változását képviselje.

3. Az irodalomban megjelent ökológiai vizsgálatok közül a) több országban végzett ökológiai vizsgálat nem tudta bizonyítani az antidepresszívumok használata és az öngyilkossági ráták közötti inverz kapcsolatot, b) vagy nem konzekvens, vegyes eredmények jelentkeztek, illetve c) számos országban előbb kezdödött el az öngyilkossági ráták csökkenése, mint az antidepresszánsok használatának értékelhető emelkedése. Így történt ez Magyarországon is, ahol 6 évvel (az idősek körében 10 évvel) előbb indult el az öngyilkosságok csökkenése, mint az AD-k eladásának emelkedése. Ugyanakkor a hazai öngyilkossági ráta stagnálásának, illetve mérsékelt emelkedésének ideje alatt (2009-2010) az AD-forgalom tovább emelkedett.

4. Az eddigiekben részletezettek miatt meggyőződésünk, hogy heves presztízsviták helyett két fontos teendője lenne szakmánknak.

Az első cél, hogy a valóban depressziós betegek minél elóbb és minél magasabb számban kerüljenek adekvát kezelésbe. Ehhez a társadalom folyamatos edukációjára lenne szükség. A (major) depressziót hazánkban általában nem tekintik súlyos betegségnek, de fontos szempont a szégyenérzés („nem vagyok én bolond") vagy az információhiány. Gyakran nem ismerik fel saját bajukat, de néha még a mentálhigiénés rendszer sem. Ennek okai, hogy a panaszokat elfedhetik a szomatikus tünetek vagy valamilyen szenvedélybetegség. Sajnos sem az önpusztítás gondolatával foglalkozó ember, sem hozzátartozója nem fordul a prevenciós lehetőségekhez, amely legtöbbször a pszichiátriai ellátást jelenti hazánkban. A „fehérköpenyes” ellátás iránt viszont erős az averzió, nem véletlen, hogy a leghatékonyabb prevenciós in- 
tézmények munkatársai önkéntesek, kiképzett és mély empátiával rendelkező civilek. Többek között az ilyen típusú preventív intervencióra képes és hajlandó személyek százait kellene felfedezni és kiképezni (ingyen!) a fentebb említett társadalmi edukáció keretein belül. A képzés természetesen tartalmazná az adott esetben szükségessé váló pszichiátriai ellátásba történő irányítást is.

A szakma másik, fontos teendője, miként fentebb többször hangsúlyoztuk, egy országos monitoring bevezetésének intenzív sürgetése lenne. Ez szigorúan betartandó jelentési kötelezettséggel oldható meg, pontosan meghatározott diagnosztikus kategóriák szerint, követné a betegségek kórlefolyását, értékelné a terápia minőségi és mennyiségi paramétereit. Több, és az okokat jobban ismerő tudást és eredményeket tudnánk elérni a hazai öngyilkosság prevenciójában.

\section{Irodalom}

Ajtay, Gy., Bérdi, M., Szilágyi, S., \& Perczel-Forintos, D. (2012). Egy hatékony beavatkozás szuicid prevencióban: A problémamegoldó tréning alkalmazása a klinikumban. Psychiatria Hungarica, 27(2), 92-102.

Alameda-Palacios, J., Ruiz-Ramos, M., \& Garcia-Robredo, B. (2013). Suicide, antidepressant prescription and unemployment in Andalusia (Spain). Gaceta Sanitaria, 28(4), 309-312.

Aursnes, I., Tvete, I.F., Gaasemyr, J., \& Natvig, B. (2006). Even more suicide attempts in clinical trials with paroxetine randomised against placebo. BMC Psychiatry, 6:55. Doi: 10.1186/1471-244X-6-55

Baldessarini, R.J., Tondo, L., Strombom, I.M., Dominguez, S., Fawcet, J., Licinio, J., és mtsai. (2007). Ecological studies of antidepressant treatment and suicidal risks. Harvard Review of Psychiatry, 15(4), 133-145.

Bánfalvi, A. (2003). A „törvényen kívüli” szomorúság. Lege Artis Medicinae, 13(7), 576-577.

Barbui, C., Campomori, A., D’ Avanzo, B., Negri, E., \& Garattini, S. (1999). Antidepressant drug use in Italy since the introduction of SSRIs: national trends, regional differences and impact on suicide rates. Social Psychiatry and Psychiatric Epidemiology, 34(3), 152-156.

Beck, A.T., Steer, R.A., Sanderson, W.C., \& Skeie, T.M. (1991). Panic disorder and suicidal ideation and behavior: discrepant findings in psychiatric outpatients. American Journal of Psychiatry, 148(9), 1195-1199.

Biddle, L., Brock, A., Broockes, S.T., \& Gunnell, D. (2008). Suicide rates in young men in England and Wales in the 21st century: time trend study. British Medical Journal, 336:539. Doi:10.1136/bmj.39475.603935.25

Bjarnason, O. (1982). Association between changes in psychiatric services and increases in suicide rates. Archiv für Psychiatrie und Nervenkrankheiten, 232(1), 15-23.

Bostwick, J.M., \& Pankratz, V. (2000). Affective disorders and suicide risk: A reexamination. American Journal of Psychiatry, 157(12), 1925-1932.

Bramness, J.G., \& Walby, F. (2009). Ecological studies and the big puzzle of falling suicide rates. (Editorial) Acta Psychiatrica Scandinavica, 119(3),169-170.

Brown, G.K., Have, T., Henriques, G.R., Xie, S.X., Hollander, J.E., Beck, A.T. (2005) Cognitive therapy for the prevention of suicide attempts: a randomized controlled trial. JAMA, 294(5), 563-570. 
Buda, B. (2010). A devianciák medikalizációja - különös tekintettel a pszichiátria és a „pszichokultúra” szerepére. In Mészáros J., \& Harcsa I. (Szerk.), A krízis mint esély (2952). Budapest: Barankovics István Alapítvány - Gondolat

Buda, B. (2011). Az elme gyógyítása. Budapest: Háttérkiadó

Burgess, P., Pirkis, J., Jolley, D., Whiteford, H., \& Saxena, S. (2004). Do nations' mental health policies, programs and legislation influence their suicide rates? An ecological study of 100 countries. Australian and New Zeeland Journal of Psychiatry, 38(11-12), 933939.

Cougnard, A., Verdoux, H., Grolleau, A., Moride, Y., Begaud, B., \& Tournier, M. (2009). Impact of antidepressants on the risk of suicide in patients with depression in real-life conditions: a decision analysis model. Psychological Medicine, 39(8), 1307-1315.

Cox, B.C., Direnfeld, D.M., Swinson, R.P., \& Norton, G.R. (1994). Suicidal ideation and suicide attempts in panic disorder and social phobia. American Journal of Psychiatry, 151(6), 882-888.

Dahlberg, M., \& Lundin, D. (2005). Antidepressants and the suicide rate: is there really a connection? In B. Lindgren, \& M. Grossman (Eds.) Substance Use: Individual Behaviour, Social Interactions, Markets and Politics (Advances in Health Economics and Health Services Research, Vol. 16) (121-141). Bingley: Emerald Group Publishing Limited

De Leo, D. (2004). Suicide prevention is far more than a psychiatric business. World Psychiatry, 3(3), 155-156.

De Leo, D., Draper, B.M., Snowdon, J., \& Kölves, K. (2013). Suicides in older adults: a casecontrol psychological autopsy study in Australia. Journal of Psychiatric Research, 47(7), 980-988.

De Leo, D., \& Francz, C.P. (2002). Why are we not getting any closer to preventing suicide? (Editorial) British Journal of Psychiatry, 181(5), 372-374.

Default, B., \& Klar, N. (2011). The quality of modern cross-sectional ecologic studies: A bibliometric review. American Journal of Epidemiology, 174(10), 1101-1107.

Didham, R.C., Mcconnel, D.W., Blair, H.J., \& Reith, D.M. (2005). Suicide and self harm following prescription of SSRI and either antidepressants: confounding by indication. British Journal of Clinical Pharmacology, 60(5), 519-525.

Draper, B.M. (2003). Antidepressant prescribing and suicide: Associations attribute possible causality inappropriately. (Letter) British Medical Journal, 327(7409), 288.

Engelberg, H. (1992). Low serum cholesterol and suicide. Lancet, 339(8795), 727-729.

Fergusson, D., Doucette, S., Cranley Glass, K., Shapiro, S., Healy, D., Hebert, P., et al. (2005). Association between suicide attempts and selective serotonin reuptake inhibitors: Systematic review of randomized controlled trials. British Medical Journal, 330(7488), 396. Doi: $10.1136 /$ bmj.330.7488.396

Fournier, J.C., De Rubeis, R.J., Hollon, S.D., Dimidjian, S., Amsterdam, J.D., Shelton, R.C., et al. (2010). Antidepressant drug effects and depression severity: a patient-level metaanalysis. JAMA, 303(1), 47-53.

Friedman, S., Jones, J.C., Cherneb, L., \& Barlow, D.H. (1992). Suicidal ideation and suicide attempts among patients with panic disorder: a survey of two outpatients clinics. American Journal of Psychiatry, 149(5), 680-685.

Gelenberg, A.J., Thase, M.E., Meyer, R.E., Goodwin, F.K., Katz, M.M., Kraemer, H.C., et al. (2008). The history and current state of antidepressant clinical trial design: a call to action for proof-of-concept studies. Journal of Clinical Psychiatry, 69(10), 1513-1528.

Gibbons, R.D., Hur, K., Bhaumik, D.K., \& Mann, J.J. (2005). The relationship between antidepressant medication use and rate of suicide. Archives of General Psychiatry, 62(2), 165-172. 
Goldney, R.D. (2000). Prediction of suicide and attempted suicide. In K. Hawton, \& K. Van Heeringen (Eds.), The International Handbook of Suicide and Attempted Suicide (585-595). Chichester: John Wiley \& Sons

Golier, A., Marzuk, P.M., Leon, A.C., Weiner, C., \& Tardiff, K. (1995). Low serum cholesterol level and attempted suicide. American Journal of Psychiatry, 152(3), 419-423.

Greenland, S. (1992). Divergent biases in ecologic and individual-level studies. Statistics in Medicine, 11(9), 1209-1223.

Greenland, S., Robins, J. (1994). Invited commentary: ecologic studies-biases, misconceptions, and counterexamples. American Journal of Epidemiology, 139(8), 747-760.

Guaiana, G., Andretta, M., Corbari, L., Mirandola, M., Sorio, A., D’ Avanzo, B., et al. (2005). Antidepressant drug consumption and public health indicators in Italy, 1955 to 2000. Journal of Clinical Psychiatry, 66(6), 750-755.

Guaiana, G., Andretta, M., Griez, E., Biancosino, B., \& Grassi, L. (2011). Sales of antidepressants, suicides and hospital admissions for depression in Veneto Region, Italy, from 2000 to 2005: an ecological study. Annals of General Psychiatry, 10:24. Doi: 10.1186/1744-859X$10-24$

Gunnell, D. \& Frankel, S. (1994). Prevention of suicide: aspiration and evidence. British Medical Journal, 308(6938), 1227-1233.

Gusmão, R., Quintão, S., McDaid, D., Arensman, E., Van Audenhove, Ch., Coffey, C., et al. (2013). Antidepressant utilization and suicide in Europe: an ecological multi-national study. PloS ONE, 8(6), e66455. Doi:10.1371/journal.pone.0066455

Guze, S.B., \& Robins, E. (1970). Suicide and primary affective disorders. British Journal of Psychiatry, 117(539), 437-438.

Hawton, K., Appleby, L., Platt, S., Foster, T., Cooper, J., Malmberg, A., et al. (1999). The psychological autopsy approach to studying suicide: a review of methodological issues. Journal of Affective Disorders, 50(2-3), 269-276.

Hawton, K., Arensman, E,. Townsend, E., Bremner, S., Feldman, E., Goldney, R., et al. (1988). Deliberate self-harm: systematic review of efficacy of psychosocial and pharmacological treatments in preventing repetition. British Medical Journal, 317, 441-447.

Helgason, T., Tómasson, H., \& Zoega, T. (2004). Antidepressants and public health in Iceland. Time series analysis of national data. British Journal of Psychiatry, 184, 157-162.

Joannidis, J.P. (2008). Effectiveness of antidepressants: an evidence myth constructed from a thousand randomized trials? Philosophy, Ethics, and Humanities in Medicine, 3:14. Doi: 10.1186/1747-5341-6-8

Johannessen, H., Dieserud, G., Claussen, B., \& Zahl, P-H. (2011). Changes in mental health services and suicide mortality in Norway: an ecological study. BMC Health Services Research, 11:68. doi: 10.1186/1472-6963-11-68.

Kamat, M.A., Edgar, L., Niblock, P., McDowell, C., \& Kelly, C.B. (2014). Association between antidepressant prescribing and suicide rates in OECD countries: an ecological study. Pharmacopsychiatry, 47(1), 18-21.

Kapusta, N.D., Niederkrotenthaler, T., Etzersdorfer, E., Voracek, M., Dervic, K., Jandl-Jager, E., et al. (2009). Influence of psychotherapist density and antidepressant sales on suicide rates. Acta Psychiatrica Scandinavica, 119(3), 236-242.

Kelly, C.B., Ansari, T., Rafferty, T., \& Stevenson, M. (2003). Antidepressant prescribing and suicide rate in Northern Ireland. European Psychiatry, 18(7), 325-328.

Kéri, Sz. (2008). Hatástalan antidepresszívumok? Neuropsychopharmacologia Hungarica, 10(3), 117-118.

Kessler, R.C., Berglund, P., Borges, G., Nock, M., \& Wang, P.S. (2005). Trend in suicide ideation, plans, gestures and attempts in the United States, 1990-1992 to 2001-2003. JAMA, 293(20), 2487-2495. 
King, G. (2013). A Solution Inference Problem. Princeton: Princeton University Press

Kirsch, I. (2009). Antidepressants and the placebo response. Epidemiologia e Psichiatria Sociale, 18(4), 318-322.

Kirsch, I., Deacon, B.J., Huedo-Medina, T.B., Scoboria, A., Moore, T.J., \& Johnson, B.T. (2008). Initial severity and antidepressant benefits: a meta-analysis of data submitted to the Food and Drug Administration. PLOS Med, 5(2): e45. Doi: 10.1371/journal.pmed.0050045

Kmetty, Z., Bozsonyi, K., \& Zonda, T. (2016). A magyar öngyilkossági adatok ökológiai vizsgálata komplex statisztikai módszerekkel. Psychiatria Hungarica, 31(1), 5-14.

Kovács, J. (2007). Bioetikai kérdések a pszichiátriában és a pszichoterápiában. Budapest: Medicina Könyvkiadó

KSH (2011). Egészségügyi Statisztikai Évkönyv. 2010. Budapest: Központi Statisztikai Hivatal

Largey, M., Kelly, C.B., \& Stevenson, M. (2009). A study of suicide rates in Northern Ireland 1984-2002. Ulster Medical Journal, 78 (1), 16-20.

Ludwig, J., Marcotte, D.E., \& Norberg, K. (2009). Antidepressants and suicide. Journal of Health Economics, 28, 659-676.

Mäkinen, I.H. (2000). Eastern European transition and suicide mortality. Social Science and Medicine, 51(9), 1405-1420.

Manfredini, R., Caracciolo, S., Salmi, R., Boari, B., Tomelli, A., \& Gallerani, M. (2000). The association of low serum cholesterol with depression and suicidal behaviours: new hypotheses for the missing link. The Journal of International Medical Research, 28(6), 247257.

Martinez, C., Rietbrock, S., Wise, L., Ashby, D., Chick, J., Moseley, J., et al. (2005). Antidepressant treatment and the risk of fatal and non-fatal self harm in first episode depression: nested case-control study. British Medical Journal, 330(7488):389. Doi: 10.1136/ bmj.330.7488.389

Melander, H., Ahlquist-Rastad, J., Meijer, G., \& Beermann, B. (2003). Evidence b(i)ased medicine-selective reporting from studies sponsored by pharmaceutical industry: review of studies in new drug applications. British Medical Journal, 326(7400), 1171-1173.

Moncrieff, J. (2003). Antidepressant scribing and suicide: Analysis is misleading. (Letter) British Medical Journal, 327(7409): 288. Doi: 10.1136/bmj.327.7409.288

Moncrieff, J., \& Pomerleau, J. (2000). Trends in sickness benefits in Great Britain and the contribution of mental disorders. Journal of Public Health Medicine, 22(1), 59-67.

Morgan, O.W.C., Griffiths, C., \& Majeed, A. (2004). Association between mortality from suicide in England and antidepressant prescribing: an ecological study. British Medical Journal, 4:63. Doi: 10.1186/1471-2458-4-63

Morgenstern, H. (1995). Ecological studies in epidemiology: concepts, principles and methods. Annual Review of Public Health, 16, 61 (letter).

Oravecz, R. (1999). Adalékok a "Gotland vitához". Szlovén szuicidológiai adatok alapján. Szenvedélybetegségek, 4, 209-314.

Oravecz, R., Czigler, B., \& Leskosek, F. (2003). Correlation between suicide rata and antidepressant use in Slovenia. Archives of Suicide Research, 7(3), 279-285.

Paykel, E.S. (2007). Cognitive therapy in relapse prevention in depression. The International Journal of Neuropsychopharmacology, 10(1),131-136.

Piantadosi, S., Byar, D.P., \& Green, S.B. (1998). The ecological fallacy. American Journal of Epidemiology, 127(5), 893-904.

Pikó, B. (2003). A depresszió: kórtünet és kortünet. Lege Artis Medicinae, 13(7), 576-577.

Plummer, M., \& Clayton, D. (1966). Estimation of population exposure in ecological studies. Journal of the Royal Statistical Society (B Series). 58 (1), 113-126. 
Rajkumar, A.P., Brinda, E.M., Duba, A.S., Thangadurai, P., \& Jacob, K.S. (2013). National suicide rates and mental health system indicators: An ecological study of 191 countries. International Journal of Law and Psychiatry, 36(5-6), 339-342.

Reseland, S., Bray, I., \& Gunnel, D. (2006). Relationship between antidepressant sales and secular trends in suicide rates in the Nordic countries. British Journal of Psychiatry, 188, 354-358.

Rihmer, Z., Belső, N., \& Barsi J. (1994). Szuicid magatartás vizsgálata ambulánsan kezelt pánikbetegeknél. Psychiatria Hungarica, 9(6), 549-553.

Robinson, W.S. (1950). Ecological correlations and the behavior of individuals. American Sociological Review, 15(3) 351-557.

Roose, S.P., Sackeim, H.A., Krishnan, K.R., Pollock, B.G., Alexopoulos, G., Lavretsky, H., et al. (2004). Antidepressant pharmacotherapy in the treatment of depression in the very old: a randomized, placebo-controlled trial. American Journal of Psychiatry, 161(11), 2050-2059.

Rudd, M.D., Dahm, P.F., \& Rajab, M.H. (1993). Diagnostic comorbidity in persons with suicidal ideation and behavior. American Journal of Psychiatry, 150(6), 928-934.

Safer, D.J., \& Zito, J.M. (2007). Do antidepressants reduce suicide rates? Public Health, 121(4), 74-77.

Shah, A., Bhandarkar, R., \& Bhatia, G. (2010). The relationship between general population suicide rates and mental health funding, service provision and national policy: a crossnational study. International Journal of Social Psychiatry, 56(4), 448-453.

Sinyor, M., Schaffer, A., Smart, K.A., Levitt, A.J., Lanctôt, K.L., \& Grysman, N.H. (2012). Sponsorship, antidepressant dose, and outcome in major depressive disorder: metaanalysis of randomized controlled trials. Journal of Clinical Psychiatry, 73(2), 277-287.

Søndergård, L. Kvist, K., Lopez, A.G., Andersen, P.K., \& Kessing, L.V. (2006). Temporal changes in suicide rates for persons treated and not treated with antidepressants in Denmark during 1995-1999. Acta Psychiatrica Scandinavica, 114(3), 68-76.

Szádóczky, E., Papp, Zs., Vitray, J., \& Füredi, J. (2000). A hangulat- és szorongásos zavarok előfordulása a felnőtt magyar lakosság körében. Orvosi Hetilap, 141(1), 17-22.

Szebik, I. (2014). Neuroetika. Lege Artis Medicinae, 24(4), 234-240.

Szendi, G. (2004). Antidepresszáns és placebo. Budapest: Országos Addiktológiai Intézet

Thase, M.E. (2008). Do antidepressants really work? A clinicians' guide to evaluating the evidence. Current Psychiatry Reports, 10(6), 487-494.

Titelman, D., Oskarsson, H., Wahlbeck, K., Nordentoft, M., Mehluim, L., Jiang G.X., et al. (2013). Suicide mortality trends in the Nordic countries 1980-2009. Nordic Journal of Psychiatry, 67(6) 414-423.

Towsend, E., Hawton, K., \& Altman D.G. (2001). The efficacy of problem-solving treatments after deliberate self-harm: meta-analysis of randomized controlled trials with respect to depression, hopelessness and improvement in problems. Psychological Medicine, 31(6), 979-988.

Tringer, L. (2003). Mozaik. Lege Artis Medicinae, 14(7), 530-531.

Turner, E.H., Matthews, A.M., Linardatos, E., Tell, R.A., \& Rosenthal, R. (2008): Selective publication of antidepressant trials and its influence on apparent efficacy. The New England Journal of Medicine, 358(3), 252-260.

van Praag, H.M. (2002). Why has the antidepressant era not shown a significant drop in suicide rates? Crisis, 23(2), 77-82.

van Praag, H.M. (2003). A stubborn behaviour: the failure of antidepressants to reduce suicide rates. World Journal of Biological Psychiatry, 4(4), 184-191.

Wakefield, J. (2008). Ecologic studies revisited. Annual Review of Public Health, 29, 75-90. 
Wheeler, B.W., Gunnell, D., Metcalfe, C., Stephens, P., \& Martin, R.M. (2008). The population impact on incidence of suicide and non-fatal self harm of regulatory action against the use of selective serotonin reuptake inhibitors in under 18s in the United Kingdom: ecological study. British Medical Journal, 336(7643), 542-545.

WHO (2014). European Health for All database. Letöltve: 2016. 01. 01-jén: http:/ / www.euro. who.int/en/data-and-evidence/databases/european-health-for-all-database-hfa-db

Zahl, P.H., De Leo, D., Ekeberg, Ø., Hjelmeland, H., \& Dieserud, G. (2010). The relationship between sales of SSRI, TCA and suicide rates in the Nordic countries. British Medical Centre Psychiatry, 10, 62. Doi: 10.1186/1471-244X-10-62

Zhang, J., Ma, J., Jia, C., Sun, J., Guo, X., Xu, A., et al. (2010). Economic growth and suicide rate changes: a case in China from 1982 to 2005. European Psychiatry, 25(3), 159-163.

Zimmerman, S.L. (1990). The connection between macro and micro levels: States' spending for hospitals and their suicide rates. Suicide and Life-Threatening Behaviour, 20(1), 31-55.

Zonda, T. (2013). A magyar öngyilkossági ráta csökkenésének lehetséges okai. In Filó M. (Szerk.), Halálos bün és szabad akarat. Öngyilkosság a jogtudomány tükrében (138-150). Budapest: Medicina Kiadó

Zonda, T., Bartos, É., \& Nagy, G. (2000). Az affektív zavarok felmérése egy fóvárosi kerület népessége körében. Orvosi Hetilap, 141(26), 1443-1447.

Zonda, T., Nagy, G., \& Lester, D. (2011): Panic disorder and suicidal behavior. Crisis, 32(3), 169-172.

Zonda, T., \& Paksi, B. (2001). Az alföldi-dunántúli népesség sajátos lelki alkatának, mentális állapotának komparatív vizsgálata interdiszciplináris megközelitéssel. (Kutatási beszámoló az Eü. Minisztérium felé, kézirat.) Budapest.

Zureik, M., Courbon, D., \& Ducimetière, P. (1996). Serum cholesterol concentration and death from suicide in men: Paris prospective study I. British Medical Journal, 13(7058), 649-651.

\section{Köszönetnyilvánítás}

Köszönettel tartozunk az OEP illetékes osztályának (via Egészségügyi Államtitkárság), és az IMS Hungary Kft.-nek a hazai antidepresszívumok forgalmi adatainak (2007-2010) a rendelkezésünkre bocsátásáért.

\section{Szerzói munkamegosztás}

A három szerző évek óta dolgozik együtt, több közös közleményük jelent meg, rangsorolásuk jelen esetben is nehezen szétválasztható. Első szerző főként az ökológiai közlemények irodalmi gyújtését, értékelését és a tanulmány végső formába öntését végezte. Szerzőtársai a módszertani, matematikai szakirodalom áttekintésével, a szükséges számításokkal, a kritikai megfogalmazásokkal foglalkoztak.

\section{Nyilatkozat érdekütközésról}

A szerzők ezúton kijelentik, hogy esetükben nem állnak fenn érdekütközések. 


\section{Suicide and antidepressants, ecological studies}

\section{ZONDA, TAMÁS - KMETTY, ZOLTÁN - BOZSONYI, KÁROLY}

The authors studied the connections between suicide rates and the use of antidepressants (AD) published in the literature, focusing on ecological studies. They have found a couple of practical and theoretical problems which called into question the "antidepressant theory" which argues that an increase in $\mathrm{AD}$ use is the most determinant reason of the decrease in suicide rates in the given population.

1. It is not known whether with the real use of $\mathrm{AD}$ of suicide victims the possibility of ecological fallacy is clearly implied, showing false relationships.

2. It is a fundamental problem, that correlations itself can only signal a relationship between two phenomena, but does not prove causality. The present situation is further complicated: ADs do not influence suicide directly, but they affect a psychiatric illness, an adverse reaction to which might be a suicide. ADs, therefore, are supposed to have an indirect preventive but incalculable effect of unknown magnitude on an unknown percentage of depressed patients whose number is unknown.

3. Authors have not found information about the distribution of ADs prescribed for depressives or other diseases. They had a chance to analyze an official Hungarian database and to separate the groups of patients who were prescribed ADs based on their BNO-10 codes: F00-F03; F063; F25; F30-39; F40-48; F50 and others (2007-2010). Their analysis revealed that during the period examined, only 53.93\% of the ADs were sold per year for the patients with $F 25$ and F30-39 codes, which carries a high suicide risk. Almost half of the AD user patients (46,07\%) have had other psychiatric or non-psychiatric patients with low suicide risk. Therefore the number of ADs purchasing cannot be the indicator of the number of depressed patients or their treatment.

4. Authors gathered ecological studies which found no inverse relationship between increasing $\mathrm{AD}$ prescription (use) and suicides rates, or where results were mixed (inconsistent).

Keywords: suicide; use of antidepressants; ecological studies; practical and theoretical problems 